\title{
DEPRESSIVE EFHECT OF LPINEPHRINE MEDIATED VIA ADRENERGIC BETA-RECEPTOR IN ISOLATED RAT COLON AND DUODENUM
}

\author{
Norimichi NAKAHATA, Hironori NAKANISHI and Takehiko SUZUKI \\ Department of Pharmacology, I itkushima Medical College' \\ Suritsuma-cho. Fuhushima 960. Japan
}

Accepted November 18,1976

\begin{abstract}
Diflerences in sensitivity to catecholamines between colon and duodenum were examined in tissues from the rat, monitoring the depressive effect of catecholamines (n contractile response to acetylcholine (ACh). The sensitivity of colonic tissue to $\mathrm{ACh}$ was higher than that of duodenal. Epinephrine (Ep, $10 \% \mathrm{gml}$ ) depressed the contractile response to ACh in the colonic lisste, but not in the dewdenal. The depressive effect of $F_{p}$ on the contractile response to $\mathrm{ACh}$ is attributed to the stimulation of adrenergic beta-receptors in the colonic tisste as the depression disappeared by pretreatment with propranolol $\left(10^{\circ}\right.$ " $\left.\mathrm{g} / \mathrm{ml}\right)$. There was no difference on the depressive effect of papaverine on the contractile response $10 \mathrm{ACh}$. except when low concentrations were used. Dibutyryl cyclic AMP $\left(10^{-4} \mathrm{~g} / \mathrm{ml}\right)$ depressed the contractile responses of both tissues to ACh. After trcatment with Ep $(10 \div \mathrm{g} / \mathrm{ml})$, cyclic AMP contcnt was increased in the colonic tissue but not in the duodenal. However, papaverine $\left(3 \cdots 10^{\circ}\right.$ $\mathrm{g} / \mathrm{ml})$ and a higher dose of $\mathrm{Ep}\left(10^{-1} \mathrm{~g} / \mathrm{ml}\right)$ increased cyclic AMP content in both tissues. The increase of cyclic AMP and the decrease of tension caused by Ep were not correlated in these tissues. However, a positive correlation was observed between the depressive effect of Ep on the contractile response $10 \mathrm{ACh}$ and the increase of cyclic AMP content in these lissues.
\end{abstract}

Koshiba (1) reported that catecholamines reduced the tone of colon only slightly, but depressed to a considerable extent the contractile responses 10 5-HT and ACh. On the contrary, in the duodenum, there is only a slight depressive effect of catecholamines on the responses to stimulants even though catecholamines decrease the tension (2). The depressive effects of catecholamines on the responses to various stimulants have been attributed to stimulation of beta-receptors, based on the results using three catecholaminesnorcpinephrine, epinephrine and isoproterenol (2).

Using a cumulative technique (3), we attempted to determine whether or not the depressive etfects of catecholamines are mediated via beta-receptors. The stimulation of beta-receptor is considered to activate adenylate cyclase and increase the content of intracellular adenosine 3',5-monophosphate (cyclic AMP) (4 5). How the drugs which modified intracellular content of cyclic AMP affect the contractile response to $\mathrm{ACh}$, and whether the change of content of intracellular cyclic AMP correlated with relaxation or depression of the contractile responses caused by catecholamines, were also investigated.

\section{MATERIALS AND METHODS}

Rats of either sex, weighing 150-300 g. were stumned by a blow on the head and bled 
from carotid arteries. The muscular preparations, about $1.5 \mathrm{~cm}$ of colon and duodenum, were rapidly removed and suspended in two separate organ baths each containing $20 \mathrm{ml}$ of Guddum's solution which was aerated with a mixture of $95 \% \mathrm{O}_{2}$ and $5 \% \mathrm{CO}$ and kept at $27 \mathrm{C}$. The composition of the solution was as follows: $\mathrm{NaCl} 9.0 \mathrm{~g}, \mathrm{KCl} 0.4 \mathrm{~g}, \mathrm{CaCl}$. $0.03 \mathrm{~g}, \mathrm{NaHCO}_{3} 0.15 \mathrm{~g}$ and glucose $1.0 \mathrm{~g}$ in $1000 \mathrm{ml}$ of distilled water. Isometric tensions of the longitudinal muscles of the tissues were simultaneously recorded on a pen-recorder (Nihon Kohden WI-180) through a FD pick-up (Nihon Kohden SB-1T, SB-1 TH), a carrier amplifier (Nihon Kohden RP-3) and a DC amplifier (Nihon Kohden AD-22). The resting tension was adjusted to 1.0 to 1.5 is at the beginning of the experiments, but the tension usually fluctuated during the experiment. The drugs used were epinephrine hydrochloride (Ep), acetylcholine chloride ( $\mathrm{ACh}$ ), tolazoline hydrochloride, propranolol hydrochloride, papaverine hydrochloride and dibutyryl adenosine $3^{\prime}, 5^{\prime}$-monophosphate (dibutyryl cyclic AMP).

A cumulative technique was used. The challenged concentrations were $10^{-9}$ to $10^{-3} \mathrm{~g} /$ ml for the dose-response curves of AC $h$. The obtained contratile response was calculated as a percent of the maximum response to $\mathrm{ACh}$.

Content of cyclic AMP in the tissues was determined by the binding protein method. according to Yajima and Ui (6). Cyclic AMP binding protein was obtained from rat liver as follows: the homogenate of rat liver in $0.25 \mathrm{M}$ sucrose was centrifugated $(20,000 \mathrm{~g})$. To the supernatant was added $\left(\mathrm{NH}_{4}\right)_{2} \mathrm{SO}_{4}$ to make a final concentration of $30 \%$ " The precipitate was dissolved in $10 \mathrm{mM}$ Tris buffer $(\mathrm{pH} 7.5)$ containing $6 \mathrm{mM}$ mercaptoethanol and glycerol, final concentration of which was $10^{\circ}{ }_{p}$. The preparation was dialyzed overnight against a large volume of the same buffer (7). The solution was stored at 20 ( for about 6 months without loss of cyclic AMP binding activity. The tissues (about $200 \mathrm{mg}$ ), which were suspended in Guddum's solution at $27 \mathrm{C}$, were aerated with a mixture of $95 \% \mathrm{O}_{2}$ and $5 \% \mathrm{CO}_{2}$ for $1 \mathrm{hr}$, then rapidly frozen with liquid nitrogen. These frozen tissues were homogenized with $6 \%$ of $\mathrm{HClO}_{4}$ and $5^{\circ}{ }^{\prime}$ of EDTA in the final concentration. After centrifugation, supernatant neutralized with $\mathrm{KOH}$ was applied to a short column $(0.5 \div 3.0 \mathrm{~cm})$ of dry alumina (aluminum oxide, active, neutral, Merck), which was eluted with $5 \mathrm{ml}$ of 10 $\mathrm{mM}$ Tris buffer ( $\mathrm{pH}$ 7.5) to remove ATP, ADP and AMP (8). The assily mixture consisted of $0.1 \mathrm{mM}$ of the tissue extract, $0.1 \mathrm{mM}$ of binding protein $(0.07 \mathrm{mg})$ and $0.1 \mathrm{ml}$ of $0.1 \mathrm{M}$ Tris buffer ( $\mathrm{pH} 7.6$ ) containing $0.01, " \mathrm{Ci}$ of ${ }^{3} \mathrm{H}$-cyclic AMP (The Radio Chemical Center). The mixture was incubated al $0^{\circ} \mathrm{C}$ for $120 \mathrm{~min}$. Immediately after $1 \mathrm{ml}$ of dextran coated charcoal $(1 \mathrm{~g}$ of Norit Extra, $150 \mathrm{mg}$ of dextran and $1 \mathrm{~g}$ of bovine serum albumin in $300 \mathrm{ml}$ of water) had been added, the preparation was centrifugated for 5 min. ${ }^{3}$ H-cyclic AMP bound to the binding protein in the supernatant $(0.5 \mathrm{ml})$ was counted with a liquid scintillation counter, using $5 \mathrm{ml}$ of toluene-based scintillator, the composition being as follows: 2,5-diphenyloxazole (PPO) $4.0 \mathrm{~g}$, 1.4-Bis(2-(5-phenyloxazolyl))-henzene (POPOP) $0.1 \mathrm{~g} \mathrm{in}$ $1000 \mathrm{ml}$ of toluene and $500 \mathrm{ml}$ of triton $\mathrm{X}-100$.

The statistical difference of the obtatined values was determined using Student's $t$-test. 


\section{RESUITS}

Sensitivity to ACh and the effect of aphephine on the contractile response to ACh

Administration of $\mathrm{ACh}$ increased tension in the intestine. Sensitivily of the colonic tissuc to $\mathrm{ACh}$ was higher than that of the duodenal. The $\mathrm{pD}$, values, which indicate a negative logarithm of $50 \%$ of effective molar doses, were $7.27 \cdots 0.13(\mathrm{~N}=7)$ in the colonic tissue and $6.57 \cdots 0.13(\mathrm{~N}-7)$ in the duodenal. The difference was statistically significant (P. 0.01$)$. Figs. 1 and 2 show the eflect of Ep $\left(10^{-i} \mathrm{~g} / \mathrm{ml}\right)$ on the cumulative dose-response curves of ACh. The contractile response of the colonic tissue to lower concentration of ACh was more markedly depressed with treatment of Ep $\left(10^{-} \mathrm{g} / \mathrm{ml}\right)$ than was that of the duodenal. However. the contractile response 10 a higher concentration of ACh was potentiated with the treatment of $\mathrm{Ep}\left(10^{-\mathrm{i}} \mathrm{g} / \mathrm{ml}\right)$ in both tissues. In the present study, we examined the depressive effect of Ep.

Fig. 1. Lllec of epinephrine on the contractile response to ACh, using a cumulative lechnique. ACh was added as follows: $10^{3}, 3,10^{-4}, 10^{*}, 3,10^{\circ}, 10^{-5}, 310^{\circ}$. $10^{\circ}, 3 \cdot 10^{\circ}$ and $10^{\circ} \mathrm{g} \mathrm{ml}$. Ep, $10^{\circ} \mathrm{g} \mathrm{ml}$, was added 2 min before administration of $\mathrm{ACh}$.

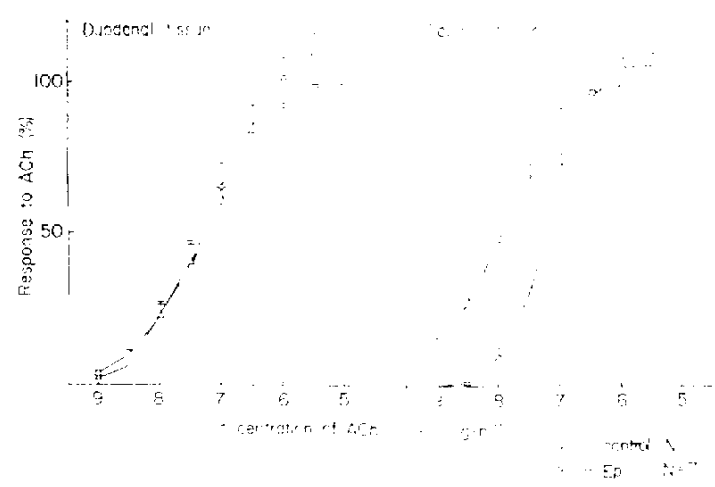

Fig. 2. Ellect of epinephrine on the contractile response to ACh. Ep, io $\mathrm{gml}$. treatment was given 2 min before administration of ACh. Data was calculated as a maximum contractile response to ACh was 100 . The mean of maximum cension of duodenal tissue indueed by $\wedge \mathrm{C}$ h was $3.60=0.26 \mathrm{~g}(\mathrm{~N} .7)$, and that of colonic lisstue was $3 . \times 2 \quad 0.639$ (N 71 . I : standard error 


\section{Effect of whazoline}

Contractile responses of both tissues to ACh were not modified when treated with tolazoline $\left(10^{-3} \mathrm{~g} / \mathrm{ml}\right)$ alone. The depressive effect of $\mathrm{Ep}\left(10^{-} \mathrm{g} / \mathrm{ml}\right)$ on the contractile response of the colonic tissue to $\mathrm{ACh}$ did not change with the combined administration of tolazoline $\left(10^{-5} \mathrm{~g} / \mathrm{ml}\right)$ and $\mathrm{Ep}\left(10^{--} \mathrm{g} / \mathrm{ml}\right)$ (Fig. 3). This finding indicates that the depressive effect of Ep was not due to stimulation of the adrenergic alpha-receptors.

The combined administration of tolazoline $\left(10^{-5} \mathrm{~g} / \mathrm{ml}\right)$ and $\mathrm{Ep}\left(10^{--} \mathrm{g} / \mathrm{ml}\right)$ as well as Ep alone did not depress the contractile response of the duodenal tissuc to ACh (Fig. 3).

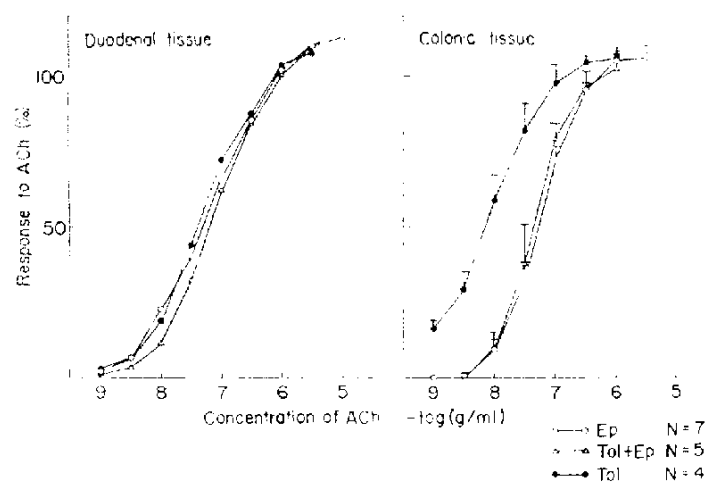

FIs. 3. Modification of Ep-induced depressive effect on the contractile response io ACh by tolazoline. Ep, $10^{-} \mathrm{ig} / \mathrm{ml}$, treatment was given 2 min before administration of $\mathrm{ACh}$, and Tol. $10^{-\overline{-}} \mathrm{g} \cdot \mathrm{ml}$, treatment was given 5 min hefore administration of Ep. I: standard error

\section{Effect of propranolol}

The contractile response to $\mathrm{ACh}$ was slightly decreased with pretreatment of propranolol $\left(10^{-5} \mathrm{~g} / \mathrm{ml}\right)$ alone in both the colonic tissue and the duodenal tissue. The depressive effect of propranolol was more clearly evident in the duodenal tissue than in the colonic tissue (Figs. 2 and 4). In contrast to Ep, propranolol reduced the maximum response to ACh in the duodenal tissue. The possibility that propranolol acted not only as an adrenergic beta-blocking agent but atso as a direct muscle relaxant had to be considered. The combined administration of propranolol $\left(10^{-6} \mathrm{~g} / \mathrm{ml}\right)$ and $\mathrm{Ep}\left(10^{\mathrm{i}} \mathrm{g} / \mathrm{ml}\right)$, depressed to a greater extent the contractile response to ACh than did tp alone in duodenal tissue. This effeet, however, was weaker than the depressive effect of propranolol alone. On the other hand, the depressive effect of $\mathrm{Ep}\left(10^{-i} \mathrm{~g} / \mathrm{ml}\right)$ was counteracted by pretreatment with propranolol $\left(10^{-6} \mathrm{~g}\right.$; $\mathrm{ml}$ ) in colonic tissue. These findings indicate that the depressive effect of $\mathrm{EP}$ on the contractile response of the colonic tissue to $\mathrm{ACh}$ was produced by stimulation of adrenergic beta-receptors.

\section{Effect of paparerin}

The pattern of the depressive effect of papaverine on the contractile response to $\mathrm{ACh}$ was different from that of Ep; that is, papaverine depressed the maximum response to $\mathrm{ACh}$ 

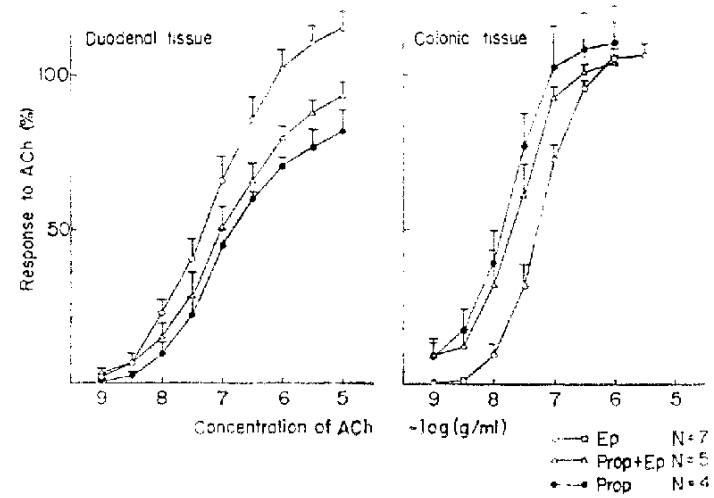

Fig. 4. Modification of Ep-induced depressive effect on the contractile response to $\mathrm{ACh}$ by propranolol. Ep, $10^{-\tau} \mathrm{g} / \mathrm{ml}$, treatment was given $2 \mathrm{~min}$ before administration of $\mathrm{ACh}$, and Prop, $10^{-6} \mathrm{~g} / \mathrm{ml}$, treatment was given $5 \mathrm{~min}$ before administration of Ep. I: standard error

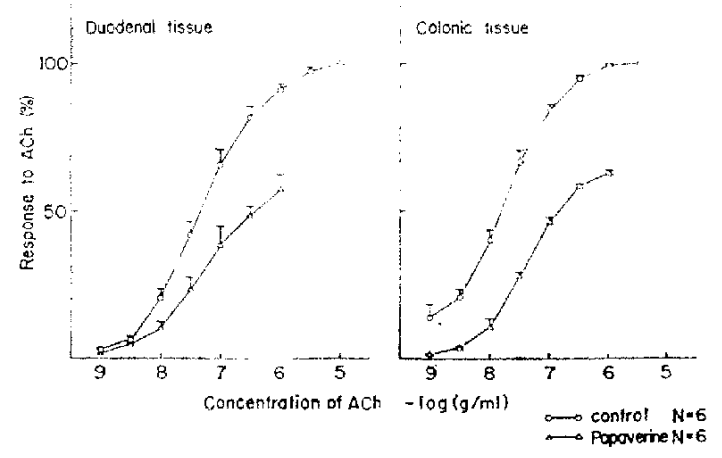

Fici. 5. Effect of papaverine on the contractile response to ACh. Papaverine hydrochloride, $3 \quad 10^{-6} \mathrm{~g} / \mathrm{ml}$, treatment was given $2 \mathrm{~min}$ before administration of $\mathrm{ACh}$. I: standard error

(Fig. 5). The $\mathrm{pD}_{2}$ value in colonic tissue, which indicates negative logarithm molar doses of non-competitive antagonists that depress $50 \%$ of the maximum response of agonists, was $4.99 \div 0.02(\mathrm{~N}=6)$ and that of duodenal tissue was $5.07 \pm 0.04(\mathrm{~N}=6)$. The difference of $\mathrm{pD}_{2}^{\prime}$ values between the two tissues was statistically insignificant. With lower concentrations of ACh such as $10^{-3}-10^{-4} \mathrm{~g} / \mathrm{ml}$, however, the depressive effect of papaverine on the contractile response to $\mathrm{ACh}$ was more remarkable in colonic tissue than in duodenal tissue.

\section{Effect of dibutyryl cyclic $3^{\prime}, 5^{\prime}-A M P$}

Dibutyryl cyclic AMP is considered to pass through the cell membrane into the intracellular fluid, and administration of dibutyryl cyclic AMP increases the content of intracellular cyclic AMP (9). Dibutyryl cyclic AMP $\left(10^{-4} \mathrm{~g} / \mathrm{ml}\right)$ produced a depression of the contractile response to $\mathrm{ACh}$ in both tissues (Fig. 6). The depressive effect of dibutyryl 


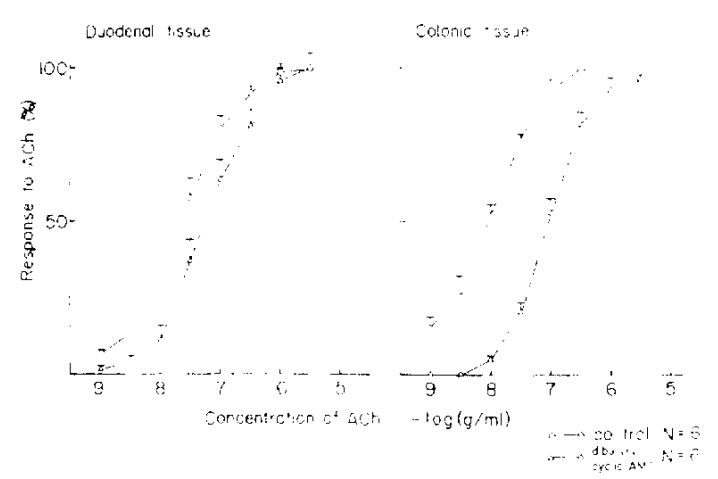

Fic. 6. Effect of dibutyryl cyclic AMP on the contractile response to $\mathrm{ACh}$. Dibutyryl cyclic AMP, $10^{-4} \mathrm{~g}$ 'ml. treatment was given 10 min before administration of $\mathrm{ACh}$. I: standard error

cyclic AMP was similar to that of Ep at the point of no depression of maximum response to $\mathrm{ACh}$. The contractile response of the colonic tissue to $\mathrm{ACh}$ was depressed to a greater extent with the treatment of dibutyryl cyclic AMP $\left(10^{-+} \mathrm{g} / \mathrm{ml}\right)$. The finding that dibutyryl cyclic AMP depressed the contractile response to $\mathrm{ACh}$ in both tissues in a similar manner to Ep in the colonic tissue suggests that the depressive effect of Ep may be related to increase in intracellular cyclic AMP.

\section{Effect of Ep and papaverine on content of intracellutar cyclic AMP}

The present findings suggest that the depressive effect of $E_{p}$ on the contractile response of colonic tissue to ACh may be due to stimulation of adrenergic beta-receptors. If such is the case, intracellular cyclic AMP content increased with the treatment of Ep. Cyclic AMP content of both tissues was determined in the same situation when mechanical movement was recorded. Table 1 shows the effect of both relaxants on cyclic AMP content (a), relaxing effects (b) and depressive effects on contratile response $10 \mathrm{ACh}\left(10^{-4} \mathrm{~g} / \mathrm{m}\right)$ ) (c). Relaxants were applied 2 min before sampling of tissues, when cyclic AMP content was determined. Ep $\left(10^{-i} \mathrm{~g} / \mathrm{ml}\right)$ increased the intracellular cyclic AMP content in colonic tissue, but not in duodenal tissue. Relaxing effect of $\operatorname{Ep}\left(10^{--} \mathrm{g} / \mathrm{ml}\right)$ was, however, observed in duodenal tissue. Under the same circumstances, the depressive effect of $E p\left(10^{-i} \mathrm{~g} / \mathrm{ml}\right)$ on the contractile response of duodenal tissue $10 \mathrm{ACh}\left(10^{*} \mathrm{~g} / \mathrm{ml}\right)$ was not observed. On the other hand, Ep $\left(10^{-7} \mathrm{~g} / \mathrm{ml}\right)$ increased cyclic AMP content in colonic tissue significantly, though relaxation was not observed. Again, under the same circumstances. Ep ( $10 ; \mathrm{g} / \mathrm{ml})$ depressed the contractile response of colonic tissule to $\mathrm{ACh}\left(10^{-\alpha} \mathrm{g} / \mathrm{ml}\right)$.

A higher dose of $\mathrm{Ep}\left(10^{\circ} \mathrm{g} / \mathrm{ml}\right)$ increased cyclic AMP content in both tissues. Fp $\left(10^{-6} \mathrm{~g} / \mathrm{m} \mathrm{l}\right)$ depressed the contractile response to $\mathrm{ACh}$ and relaxed the muscle in both tissues. Papaverine $\left(3 \times 10^{-5}, \mathrm{~g} / \mathrm{ml}\right)$ increased cyclic AMP content significanlly and depressed the contractile response to $\mathrm{ACh}$ in both tissues. These results indicate that the depressive effect of Ep is clearly associated with change in intracellular cyclic AMP content, though the relaxing effect did not parallel the change in intracellular cyclic AMP content. 
TABut 1. Effects of epinephrine and papaverine on intracellular cyclic AMP contents (a) and relaxing effects (b) and depressive effects on contractile response to ACh (c)

(a) Cyclic AMP content ( $p$ mole/mg wet weight)

Control Ep $10^{-i} \mathrm{~g} m$

Duodenal tissue

0.32

$0.03(14)$

$0.31+0.03(7)$

Colonic tissue

$0.02(14)$

$0.52 \quad 0.05(8)^{* * *}$

$$
\text { Ep } 10^{-6} \mathrm{~g} \mathrm{ml}
$$

$0.55 .0 .06(4)^{* * *}$

$0.610 .06(4)^{* 2}$

Papaverioc 3. $10^{-16} \mathrm{~g} / \mathrm{mll}$

$0.52+0.06(4)^{k k}$

$0.47 \div 0.05(5)^{*}$

(b) Relaxing effect (g)

$\begin{array}{lllllll}\text { Diodenal tissuc } & & 1.07 & 0.10(11) & 1.37 & 0.13(7) & 0.68: 0.08(6) \\ \text { Colonic tissue } & - & 0.08 & 0.20(11) & 0.35: 0.09(7) & 0.20: 0.05(6)\end{array}$

(c) Depressive effect $(\%$ of the response to Ach)

\begin{tabular}{|c|c|c|c|c|c|}
\hline Duodenal tissue & 100 & 116.5 & $8.55(7)$ & $25.5 \quad 3.19(6)^{* 1:}$ & $45.2 \quad 6.85(6)^{2 \cdot 2}$ \\
\hline Colonic tissue & 100 & 23.8 & $781(7)^{* * *}$ & $7.12(6)^{*}$ & $30.7 \cdot 6.76(6)^{*}$ \\
\hline
\end{tabular}

Cyclic AMP content was calculated per mg of tissue, wet weight. In colonic tissue the increasing actions of Ep $\left(10^{-7}, 10^{-6} \mathrm{~g} \mathrm{ml}\right)$ and papaverine on intracellular cyclic AMP content were significant (*: $\mathrm{P}, 0.05, * ;: \mathrm{P}, 0.01$ ), between control value and the values treated with relaxants 2 min before sampling. In the duodenal tissuc Ep $\left(10^{-} \mathrm{g} / \mathrm{ml}\right)$ did not increase intracellular cyclic AMP. Relaxing effect means a reduction of tension from resting tension (Resting tension of duodenal tissue was $1.50 \therefore 0.08 \mathrm{~g}(\mathrm{~N}=24)$. and that of colonic tissue was $1.07 \cdot 0.06 \mathrm{~g}(\mathrm{~N}-24)$ ). Depressive effect of relaxants was cakulated as $\mathrm{ACh}\left(10^{-8} \mathrm{~g} / \mathrm{ml}\right.$ )-induced tension before relaxants was 100 (duodenal lissue: $0.940 .10 \mathrm{~g}$ (N 19), colonic lissue: 1.80$) 0.18 \mathrm{~g}(\mathrm{~N}$ 1911. 1 1: ntmber (1) animals.

\section{DISCUSSION}

Catecholamines produce relaxation in the intestine through the stimulation of adrenergic alpha- and beta-receptors $(10-13)$. It is generally accepted that the mechanism of stimulation of alpha-receptors differs from that of beta-receptors. Stimulation of alpha-receptors produced relaxation in the intestine, changing the permeability of the cell membrane to ions (13). On the other hand, stimulation of beta-receptors produced relaxation by the activation of adenylate cyclase which increases the intracellular cyclic AMP content (9. 11 ). We previously stated that using three catecholamines--.-Ep, norepinephrine and isoproterenol. the depressive effect of eatecholamines was apparently due to the stimulation of betareceptors (2).

In the present study, Ep was selected for use, as it has the ability to stimulate both alpha- and beta-receptors. The depressive effect of Ep (10 ' giml) on the contractile response to ACh was observed in the colonic tissue but not in the duodenal. The depressive effect of Ep $\left(10^{-7} \mathrm{~g} / \mathrm{ml}\right)$ in the colonic tissue was unaffected by pretreatment with tolazoline, while the effect disappeared with propranolol pretreatment. Therefore, the depressive effect of Ep on the contractile response of colonic lissue to ACh may be attributed to stimulation of adrenergic beta-receptors. Stimulation of beta-receptors reportedly increases the concentration of intracellular cyclic AMP (4-5). Papaverine, which inhibits phosphodiesterase $(14-15)$, relaxes smooth muscles. In this study, papaverine depressed the 
contractile response of both tissues to ACh. There was no difference of the depressive effect between the two tissues when the $\mathrm{pD}_{2}$ values were compared. On the other hand, papaverine $\left(3 \times 10^{-6} \mathrm{~g} / \mathrm{ml}\right)$ increased intracellular cyclic AMP content in both tissues. When the content was increased by the inhibition of phosphodiesterase, a depressive cffect on the contractile response was produced with equal value in the two tissues.

Using dibutyryl cyclic AMP, instead of cyclic AMP which scarcely passes through the cell membrane, the effect of intracellular cyclic AMP on the contractile response to ACh was examined. Dibutyryl cyclic AMP $\left(10^{-4} \mathrm{~g} / \mathrm{ml}\right)$ depressed the contractile responses of both tissues to ACh. However, a lower concentration of dibutyryl cyclic AMP $\left(10^{-5} \mathrm{~g} / \mathrm{ml}\right)$ produced no such depression (unpublished observation). The depressive effect of dibutyryl eyclic AMP was observed to be remarkable in both tissues. In the duodenal tissue, dibutyryl cyclic AMP depressed the contractile response to ACh, though Ep $\left(10^{-7} \mathrm{~g} / \mathrm{ml}\right) \mathrm{did}$ not, suggesting that increase of intracellular cyclic AMP may produce a depressive effect on the contractile response to $\mathrm{ACh}$. Ep $\left(10^{-i} \mathrm{~g} / \mathrm{ml}\right)$ increased the content of cyclic AMP significantly in colonic tissue, but not in duodenal. When cyclic AMP content was increased such as seen in colonic tissue, the depressive effect of $\mathrm{Ep}$ on the contractile response to $\mathrm{ACh}$ was observed, and when cyclic AMP content was not increased such as in the duodenal tissuc, the depressive effect of Ep was not observed. The increase of cyclic AMP was not concomitant with the relaxing effect of $\mathrm{Ep}$; for example, in the duodenum Ep $\left(10^{-3} \mathrm{~g} / \mathrm{ml}\right) \mathrm{did}$ not produce an increase in the content of cyclic AMP, though Ep $\left(10^{--} \mathrm{g} / \mathrm{ml}\right)$ did produce a marked relaxation. On the other hand, Ep $\left(10^{-7} \mathrm{~g} / \mathrm{ml}\right)$ increased the content of cyclic AMP in the colonic tissue without producing a relaxation. It has been reported that anti-spasmodics such as aspaminol produce a relaxation without increase of intracellular cyclic AMP content (15). The present data is consistent with above-mentioned results regarding the data that relaxation did not always accompany the increase of cyclic AMP content. A higher dose of $\mathrm{Ep}\left(10^{-6} \mathrm{~g} / \mathrm{ml}\right)$ increased the intracellular content of cyclic AMP, accompanied with the depressive effect on the contractile response to ACh not only in colonic tissuc but also in duodenal. These results indicate that the change of cyclic AMP content is related to the depressive effect on the contractile response to $\mathrm{ACh}$ rather than to the relaxing effect. It appears that the sensitivity of the colonic tissue to adrenergic beta-receptors is higher than that of duodenal, and that the depressive effect of eatecholamines on the contractile response 10. ACh is mediated via adrenergic beta-receptors.

Acknowledgements: The authors are grateful to Mr. David S. Singer for assistance with the manuscript and Mrs. S. Sato for secretarial services.

\section{REFERENCES}

1) Koshiba, H. : Folia phamacol. iapon. 71, 415(1975) (in Japanese)

2) Vakahata, N.: Fukushima I. Med. Sci. 21, 41 (1975)

3) Rossum. L.M.V.: Archs int. Phamacodyn. Ther. 143, 299 (1963)

4) Bueding, F., Butcher, R.W. Hawkins, J., Timms, A.R. and Suthrrland. E.W., Jr.: Biochim. Biophys. Acta 115,173 (1966)

5 ANDERSON, R. AND MOHME-Lundholm, E.: Acra physial. sculat. 79, 244 (1970) 
6) YaJIMA, M. AND UI, M.: Am. J. Physiol. 228, 1053 (1975)

7) Kumon, A., Yamamura, H. and Nishlzuka, Y.: Biochem. biophys. Res. Commm. 41, 1290 (1970)

8) Ramachandran, J.: Analyt. Biochem. 43, 227 (1971)

9) Robison, G.A., Butcher, R.W. and Sutherland, E.W.: Cyclic AMP, p. 98, Academic Press, New York and London (1971)

10) Ahlquist, R.P. ANo LeYY, B.: J. Pharmacol. exp. Ther. 127, 146 (1959)

11) Bucknell, A. And Whitey, B.: Brit. J. Pharmacol. 23, 164 (1964)

12) Bowman, W.C. and Holl, M.T. : Brit. J. Pharmacol. 38, 399 (1970)

13) Ahlquist, R.P.: I. Pharmacentic Sci. 55, 359 (1966)

14) Triner, L., Vullemoz, Y., Schwaktz, I. and NaHas, G.G.: Biochem. biophys. Res. Commin. 40, $64(1970)$

15) Inalomi, N. Takayanacis, I. and Takagi, K.: Japan J. Phamacol. 25, 63 (1975) 